\title{
TINGKAH LAKU MAKAN ELANG LAUT PERUT PUTIH (Haliaeetus leucogaster) DI PUSAT PENYELAMATAN SATWA TASIK OKI SULAWESI UTARA
}

\author{
Andrew Loindong*), H. Kiroh, I. Wahyuni dan J. L. P. Saerang
}

Fakultas Peternakan Universitas Sam Ratulangi Manado, 95115.

\begin{abstract}
ABSTRAK
Penelitian ini bertujuan untuk mendeskripsikan tingkah laku makan elang laut perut putih (Halliaetus leucogaster) di pusat penyelamatan satwa Tasikoki pada pemeliharaan dalam kandang sebagai salah satu strategi konservasi untuk dilakukan translokasi. Metode observasi dan teknik instantinous animal sampling digunakan sebanyak 14 sample dan dimulai pada jam 7.00 Wita-17.00 wita. Variabel yang diamati adalah pengamatan mangsa, pengangkapan mangsa dan memakan mangsa dari elang laut perut putih sebagai variabel dalam penelitian ini. Hasil penelitian menunjukan bahwa elang laut perut putih memakan ikan dan elang lainya (kanibal). Tingkah laku makan dipengaruhi oleh jenis makanan, yang mana makanan favorite adalah elang laut lainya dan tingkah laku agonistik hampir selalu terjadi saat memakan elang lainya. Elang laut perut putih melakukan pengamatan mangsa dan hal lain disekitar kandang dengan persentase 3\%. elang laut hanya menangkap ikan dengan persentase $1 \%$. Elang laut perut putih memakan mangsa dengan persentase $96 \%$, saat memakan ikan mereka sangat sensitif dibandingkan memakan elang lainnya.
\end{abstract}

Kata Kunci : Elang laut perut putih (Haliaeetus leucogaster), Tingkah laku makan, Pusat penyelamatan Satwa Tasikoki

\section{ABSTRACT \\ INGESTING BEHAVIOUR OF WHITE BELLIED SEA EAGLE (Haliaeetus}

leucogaster) IN TASIKOKI CENTRAL WILD ANIMAL RESCUE IN MINAHASA UTARA. This study aimed to describe the ingesting of white bellied sea eagle (Halliaetus leucogaster) in Tasikoki Central Wild Animal Rescue on safeguarding cage as one of the conservation strategy for translocation purpose. The expected benefits was to provide information about ingesting behavior of white bellied sea eagle and the reference knowledge information in the field of wild life conservation measures. This research was conducted using observational methods and instantaneous animal sampling technique of 14 animal samples. Study began at 07.00 am until $17.00 \mathrm{pm}$. The variables observed is observing prey, catching prey and ingesting prey of white bellied sea eagle as the variables of this study. The observing result is showed that white bellied sea eagle was ingesting fish and other eagle (cannibal animal). The ingesting behavior was affected by the kind of prey, which one of the favorite prey of white bellied sea eagle. The other eagle and the agonistic behavior mostly happened when they prey the other eagle. White bellied sea eagle observed the prey and other thing around the cage with the percentage of $3 \%$. White bellied sea eagle only catches fish with a percentage of $1 \%$. White bellied sea eagle was ingesting prey with a percentage of $96 \%$. The animal was very sensitive in ingesting fish more than ingesting other eagle.

Keywords : White bellied sea eagle (Halliaetus leucogaster), Ingesting Behavior, Tasikoki Central Wild Animal Rescue Tasikoki.

\footnotetext{
*Korespondensi (corresponding author):

Email: andrewloindong12@gmail.com
} 


\section{PENDAHULUAN}

Elang laut perut putih (Haliaeetus leucogaster) merupakan salah satu dari 8 spesies elang laut yang tersebar di seluruh dunia dan kawasan Sulawesi Utara merupakan salah satu habitat asli dari elang laut perut putih. Elang laut perut putih merupakan top predator dalam rantai makanan dan menempati puncak rantai makanan sehingga memiliki peran yang sangat penting dalam menjaga keseimbangan ekosistem. Elang laut perut putih merupakan satwa langka yang memiliki daerah jelajah luas dengan trend populasi menurun (IUCN, 2014) dan sangat sensitif dengan dengan gangguan (Lee et al, 2010) sehingga kehidupannya sangat rentan dan dapat menjadi indikator dalam suatu ekosistem.

Sulawesi Utara memiliki berbagai jenis satwa liar yang oleh masyarakat sering melakukan perburuan yang tidak terkendali untuk dikonsumsi atau diperlihara secara ilegal, sehingga mengkhawatirkan populasi satwa-satwa tersebut termasuk didalamnya elang laut perut putih. Pemerintah Provinsi Sulawesi Utara telah menerapkan strategi konservasi dengan membuat Pusat Penyelamatan Satwa Tasikoki di Minahasa Utara dengan bekerja sama dengan pihak swasta untuk selanjutnya melakukan translokasi di hutan Sulawesi Utara. Usaha penyelamatan elang laut perut putih sebagai indikator suatu ekosistem merupakan langkah perlindungan dan pelestarian di kawasan Sulawesi Utara (PPS Tasikoki, 2014).

Pusat Penyelamatan Satwa Tasikoki melakukan usaha penyelamatan satwa elang laut perut putih hasil sitaan dengan menggunakan metode pemeliharaan semi $E x$-situ, dimana satwa dipelihara dalam kandang yang cukup luas untuk diberi makanan tambahan serta sistem perkandangan yang sesuai agar satwa dapat beradaptasi dengan kondisi alam sebenarnya. Elang laut perut putih di Pusat Penyelamatan Satwa Tasikoki yang sebelumnya terbiasa berinteraksi dengan manusia dalam pemeliharaan Ex-situ telah memiliki tingkah laku yang berbeda dengan habitat aslinya sehingga sangat rentan untuk beradaptasi dalam pemeliharaan semi Ex-situ pada suatu proses translokasi satwa.

Metode pemeliharaan satwa yang tepat sangat berpengaruh terhadap keberhasilan translokasi satwa dan aspek tingkah laku menjadi salah satu indikator awal dalam menentukan metode pemeliharaan yang tepat (Alikodra, 2002), sehingga tingkah laku makan elang laut perut putih menjadi indikator dalam pemeliharaan semi Ex-situ karena elang laut merupakan burung pemangsa yang memiliki tingkah laku makan yang sangat berbeda dengan jenis burung lainnya. 
Tingkah laku makan elang laut perut putih (Halliaeetus leucogaster) dalam sebuah pusat penyelamatan dipelajari sehingga memberikan suatu referensi yang cukup baik untuk menentukan sistem perkandangan, pemilihan pakan dan metode pemeliharaan yang lebih tepat demi keberlangsungan hidup elang laut perut putih dalam pemeliharaan sebagai salah satu proses translokasi. Berdasarkan uraian diatas maka perlu dilakukan penelitian mengenai tingkah laku makan elang laut perut putih dalam menunjang usaha konservasi satwa langka dan endemic di Sulawesi Utara.

\section{MATERI DAN METODE PENELITIAN}

Penelitian ini dilakukan di lokasi penyelamatan satwa "Pusat Penyelamatan Satwa (PPS) Tasikoki di Desa Watudambo II Kabupaten Minahasa Utara dilakukan selama 2 minggu untuk pengambilan data yang dimulai pada bulan Maret 2015.

\section{Materi Penelitian}

Elang laut perut putih yang dipelihara dengan metode pemeliharan semi Ex-situ di Pusat Penyelamatan Satwa Tasik Oki. Jumlah materi yang digunakan dalam penelitian ini sebanyak 2 ekor (jantan) dengan makanan ikan air tawar (mujair). Penelitian ini menggunakan satu buah kandang berbentuk persegi panjang dengan ukuran $15 \mathrm{~m}(\mathrm{P}) \times 5 \mathrm{~m}(\mathrm{~L}) \times 5 \mathrm{~m}(\mathrm{~T})$ dan di dalam kandang terdapat kolam air tawar dengan ukuran $2 \mathrm{~m}(\mathrm{P})$ x $1 \mathrm{~m}(\mathrm{~L})$.

2. Metode Penelitian

Penelitian ini menggunakan metode observasi dengan prosedur pengamatan tingkah laku menggunakan teknik Focal Animal Sampling. Berdasarkan hasil studi pendahuluan dan analisis data akan disajikan secara deskriptif dan histogram.

- Prosedur Pengamatan

Pengamatan dilakukan pada pagi sampai sore hari. Waktu pengambilan data dilakukan pada 07.00 wita -17.00 wita atau 10 jam waktu pengamatan setiap hari. Durasi teknik focal animal sampling dalam satu kali pengambilan data akan menyesuaikan dengan tingkah laku makan elang laut perut putih. Pengulangan pengambilan data pada penelitian ini dilakukan sebanyak 14 kali. Dalam pengamatan yang akan dilakukan berjarak $3 \mathrm{~m}$ sampai $4 \mathrm{~m}$ dari lokasi kandang.

- Variabel Penelitian

Dalam penelitian ini dilakukan pengamatan terhadap tingkah laku makan dengan variabel penelitian yang akan diamati adalah pengamatan mangsa, menangkap mangsa dan memakan mangsa. 
- Analisis Data

Data yang diperoleh pada hasil pengamatan dianalisis dan disajikan secara deskriptif dan histogram. Deskripsi hasil penelitian akan meliputi tingkah laku makan berdasarkan variable penelitian serta parameter pada setiap variabel. Penyajian secara deskriptif dilakukan dengan melihat hasil tabulasi data mengenai presentase tingkah laku. Histogram penelitian dilakukan untuk penggambaran hubungan antara variabel yang diamati agar dapat menyimpulkan seluruh analisis deskriptif yang didapatkan dari seluruh hasil pengamatan.

\section{HASIL DAN PEMBAHASAN}

Elang laut sangat peka terhadap gangguan saat akan makan ikan di kolam dibanding sementara mengamati atau menangkap mangsa. selama pengamatan yang dilakukan sering elang laut berhenti melakukan aktivitas makan jika ada gerakan disekitarnya yang cukup mencolok, sehingga dalam melakukan dokumentasi paling efektif menggunakan handycam dan merekam aktivitasnya. Tingkah laku makan elang laut sangat sedikit selama pengamatan di Pusat Penyelamatan Satwa Tasikoki dan tidak jauh berbeda dengan aktivitas harian elang laut jenis lainya dalam pemeliharaan $E x$ -
Situ yang didominasi aktivitas stasioner (Sawitri, 2010; Wihoho et al, 2007)

Elang laut melakukan aktivitas makan dengan memakan ikan laut yang disediakan dalam kolam dan elang laut lainnya dalam kandang (kanibal). Aktivitas makan elang laut lebih tinggi saat memakan elang laut lainnya dibandingkan dengan memakan ikan yang disediakan di kolam. Tingkah laku kanibalisme yang dilakukan elang laut meningkatkan aktivitas makan dari elang laut sampai $50 \%$ dan peningkatan ini dapat menunjukan tingkat kesukaan elang laut terhadap mangsanya.

Agresifitas elang laut dalam melakukan penangkapan sangat rendah yang mana penangkapan dilakukan dengan melompat dari dinding kolam (90\%) dan sangat jarang melakukan penerbangan untuk menangkap mangsa (10\%), padahal burung elang merupakan predator tingkat tinggi (top predator) yang seharusnya lebih agresif dalam mencari dan mengejar mangsa (Sawitri, 2010) dengan penangkapan melalui manuver terbang (Tan, 2001)

Elang laut melakukan tingkah laku makan ikan air tawar dengan penggunaan waktu yang tetap. Dalam pengamatan yang dilakukan elang laut rata-rata makan 2 kali sehari dengan yakni dilakukan pada siang 
Tabel 1. Tabel Histogram Variabel Penelitian

\begin{tabular}{llll}
\hline No & Variabel & Deskripsi & \\
\hline 1 & Mengamati & Diawali dengan elang mulai mendekati dan \\
& mangsa/makanan & memperhatikan mangsa. \\
2 & Menangkap & Diawali dengan elang mulai menghampiri mangsa \\
& mangsa/makanan & dan menangkap mangsa. \\
3 & Memakan & Diawali dengan paruh elang mulai menyentuh \\
& mangsa/makanan & mangsa \\
\end{tabular}

Tabel 2. Faktor yang berpengaruh pada pengamatan elang laut.

\begin{tabular}{|c|c|c|}
\hline No & Indikator & Deskripsi \\
\hline 1 & Tempat & $\begin{array}{l}\text { - Berpindah tempat sebanyak } 2 \text { sampai } 3 \text { kali sebelum } \\
\text { mengamati mangsa. } \\
\text { - Biasanya akan turun ke tanah sebelum menangkap } \\
\text { mangsa. }\end{array}$ \\
\hline 2 & Jarak & $\begin{array}{l}\text { - Jarak tempat elang laut mengamati akan semakin dekat. } \\
\text { - Biasanya akan berdiri di dinding kolam }\end{array}$ \\
\hline 3 & Gerakan & $\begin{array}{l}\text { - Lebih sering melihat dan mengamati kolam } \\
\text { - Mudah bereaksi terhadap gerakan-gerakan disekitar } \\
\text { kandang. }\end{array}$ \\
\hline
\end{tabular}

Tabel 3. Deskripsi cara menangkap mangsa yang dilakukan elang laut.

\begin{tabular}{lll}
\hline No & Cara Menangkap & Keterangan \\
\hline 1 & Terbang & Tempat bertengger, \pm 2 sampai 4 meter dari posisi mangsa \\
2 & Melompat & Pinggir kolam. \pm 1 meter dari posisi mangsa \\
\hline
\end{tabular}

dan sore. Pada siang hari elang laut melakukan aktivitas makan antara 10.00 Wita sampai 11.00 Wita dan pada sore hari elang laut melakukan aktivitas makan antara 14.00 Wita sampai 16.00 Wita. Aktivitas memakan ikan air tawar tersebut hampir sama dengan aktivitasnya dihabitat asli yang berlangsung antara 9.00 wita sampai 15.00 wita (Cluine, 1994 dalam So dan Lee, 2010). Tingkah laku makan bangkai (kanibal) lebih variatif 
dibandingkan dengan memakan ikan air tawar. Penggunaan waktu elang laut untuk memakan bangkai pada pagi hari antara 7.00 Wita sampai 9.00 wita, siang antara 11.00 wita sampai 13.00 wita dan sore antara 15.00 wita sampai 16.00 Wita.

Perbedaan tingkah laku makan elang laut berdasarkan jenis makanan terdapat pada tahap menangkap mangsa, pada saat memakan bangkai elang laut sudah tidak perlu menangkap dan akan langsung menghampiri dan memakan mangsa. Elang laut menggunakan waktu rata-rata 4 menit 53 detik dalam aktivitas makan dengan bahan makanan berupa ikan air tawar yang berada di kolam, untuk mengamati mangsa 3\%, menangkap mangsa $5 \%$ dan $92 \%$ untuk makan. Saat melakukan kanibalisme elang laut akan menghabiskan waktu untuk mengamati $3 \%$ dan makan $97 \%$.

\section{Mengamati Mangsa}

Fase pengamatan mangsa yang dilakukan elang laut merupakan tanda awal dalam melakukan aktivitas makan. Fase ini sangat penting untuk dipelajari dalam melakukan efisiensi pengamatan tingkah laku makan elang laut perut putih. Tingkah laku mengamati mangsa yang dilakukan oleh elang laut juga dilakukan untuk mengamati lokasi sekitar kandang. Pengamatan yang dilakukan elang laut saat memakan ikan dan bangkai elang lainya tidak memiliki perbedaan yang banyak.
Pengamatan diluar kandang yang dilakukan elang laut saat menagamati ikan sebagai mangsa biasanyanya sebagai antisipasi terhadap gangguan, karena elang perut putih sangat peka dalam memakan mangsa yang telah ditangkap. pengamatan diluar kandang paling sering terjadi saat akan memakan bangkai elang lainya dibandingkan dengan memakan ikan. Kepekaan terhadap gangguan antar sesama spesies dapat dibuktikan dengan rendahnya tingkat kepadatan populasi dihabitat aslinya (IUCN, 2012).

Pengamatan elang laut dapat ditentukan dengan beberapa hal yang mempengaruhinya. Tempat, jarak dan gerakan elang laut adalah indikator yang dapat digunakan untuk mengidentifikasi dimulainya pengamatan. tempat elang laut melakukan pengamatan ditentukan dengan melihat jumlah perpindahan tempat, indikator jarak yang diamati adalah kolam lokasi mangsa dan gerakan elang laut meliputi cara pengamatan yang dilakukan.

Elang laut yang melakukan pengamatan biasanya akan mendekati lokasi mangsa yang ada di kolam dan akan mulai mengamati. Rata-rata elang laut mengamati mangsa selama 7,6 detik sebelum akhirnya melakukan penangkapan. Tahap akhir pengamatan elang laut biasanya akan diakhiri dengan posisi tubuh elang laut yang semakin 


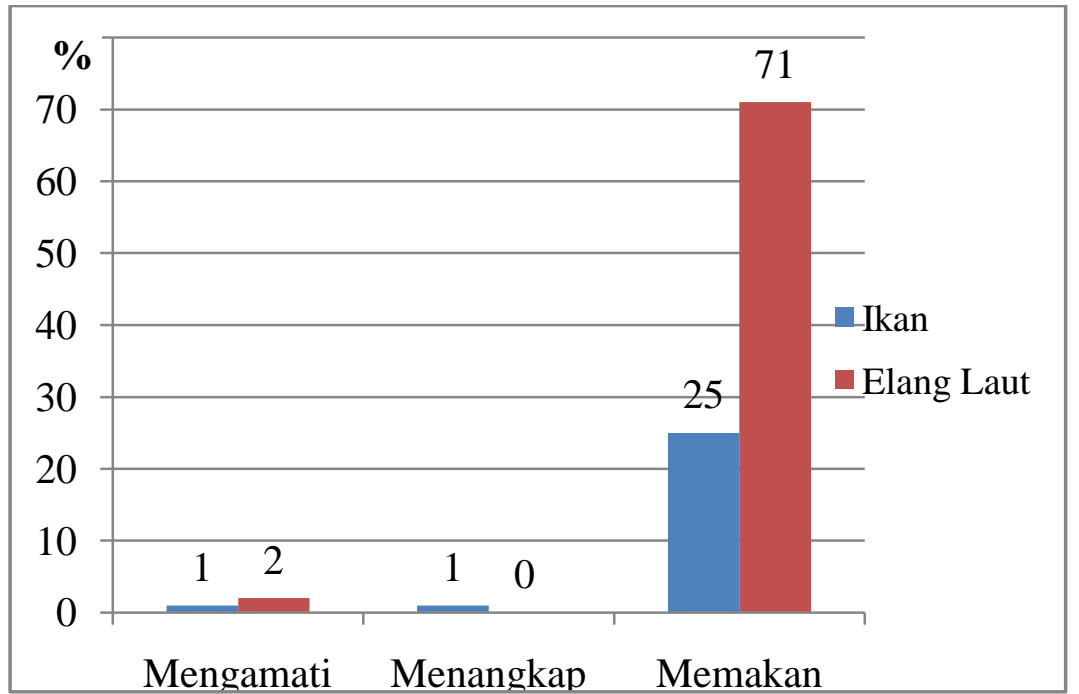

Gambar 1. Grafik perbandingan penggunaan waktu pada masing-masing tahap tingkah laku makan berdasarkan jenis makanan

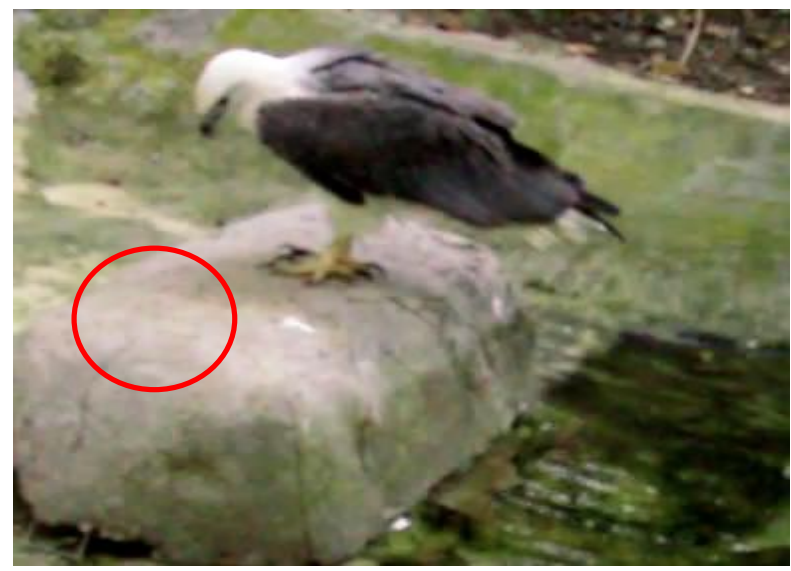

Gambar 2. Elang laut saat selesai makan ikan dari dalam kolam

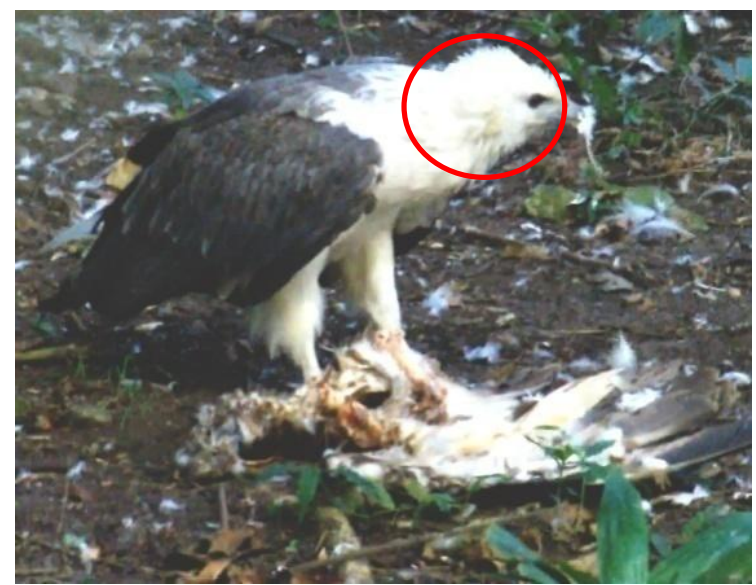

Gambar 3. Elang laut saat memakan bangkai elang lainya (kanibalisme) 
membungkuk dan bersiap untuk terbang atau melompat. Elang laut yang akan menangkap akan membungkuk cukup kebawah dan akan terlihat menatap mangsa dan kurang menghiraukan keadaan sekitar. lokasi pengamatan elang laut biasanya terjadi di pinggir kolam dan sangat jarang dilakukan ditenggeran.

\section{Menangkap Mangsa}

Cara menangkap mangsa yang dilakukan oleh elang laut sangat ditentukan dari tempat dimana elang laut akan melakukan penangkapan. Dalam menangkap mangsa elang laut menggunakan dua cara, yakni dengan cara melompat, terbang dan langsung menangkap. Biasanya elang laut hanya akan melompat dari dinding kolam untuk menangkap mangsa. $80 \%$ pengangkapan yang dilakukan elang laut dilakukan dari tanah atau dinding kolam dan $15 \%$ dilakukan dengan terbang serta 5\% dilakukan dalam kolam. Penangkapan yang dilakukan dari dalam kolam terjadi akibat kegagalan dalam usaha penangkapan pertama, yang mana kegagalan dalam usaha penangkapan pertama yang dilakukan elang laut adalah $10 \%$ dan tingkat keberhasilan dalam usaha penangkapan pertama sebanyak $90 \%$.

Elang laut memiliki dua cara yang berbeda dalam melakukan penangkapan namun tetap menggunakan kakinya untuk menangkap dan akan mematuk mangsanya serta memindahkan mangsa dari dalam kolam. Posisi tubuh elang laut dalam menangkap dengan cara mangsa adalah langsung turun dengan kaki mengarah kolam dan kepala juga menunduk mengarah kolam. Elang laut saat menangkap ikan dengan cara terbang memiliki posisi tubuh yang sedikit berbeda, awalnya kepala elang laut kedepan dan selanjutnya kaki elang laut akan kedepan saat mendekati ikan. Setelah selesai memindahkan ikan dari dalam kolam, elang laut akan mengamati sekitar sebelum memakan ikan tersebut.

\section{Memakan Mangsa}

Elang laut akan memangsa ikan yang telah ditangkapnya dengan cara mematuk ikan tersebut dan kakinya tetap menahan tubuh dari ikan tersebut meskipun telah mati. Kebanyakan waktu yang digunakan elang laut pada tahap makan adalah mengamati sekitar sambil menelan bagian tubuh ikan. Elang laut biasanya tidak akan menyisakan ikan yang dimakan bahkan elang laut akan memakan bagian tubuh ikan yang berserakan sedikit jauh dari tempat elang laut makan. Hal lain yang biasa dilakukan elang laut saat sedang makan adalah mengeluarkan suara. 
Elang laut tidak memiliki variasi dalam memakan mangsanya, meskipun memiliki beberapa cara dalam tahapan mengamati dan menangkap ikan, Tempat yang biasa dijadikan tempat untuk memakan mangsanya adalah batu kering yang berada pinggir kolam. Kemungkinan penggunaan lokasi tersebut sebagai tempat untuk makan karena tekstur yang cukup rata sehingga sangat mudah untuk melakukan aktivitas makan.

Penggunaan waktu dalam memakan ikan yang dilakukan elang laut adalah yang paling bervariasi dibandingkan dengan variabel lainnya. Tahap memakan mangsa paling cepat yang teramati adalah 120 detik dan paling lama adalah 418 detik. dalam penggunaan waktu yang cepat tersebut, elang laut hanya mendapatkan ikan yang kecil dan kemungkinan dianggap tidak terdapat gangguan yang berarti. Sementara penggunaan waktu yang paling lama terjadi akibat elang laut memakan sisa-sisa makanan yang berserakan disekitarnya.

Memakan jenisnya sendiri merupakan suatu hal yang biasa dilakukan oleh predator, apalagi dalam lokasi penyelamatan yang memberikan ruang gerak lebih kecil bagi elang laut dalam beraktivitas sehingga mempermudah melakukan perburuan terhadap sesama jenis. Meskipun kondisi kandang yang menunjang untuk menangkap ikan air tawar, namun kemungkinan besar kanibalisme terjadi akibat ketersediaan ikan yang belum cukup atau variasi makanan mempengaruhi selera makan elang laut perut putih.

$$
\text { Selama pengamatan yang }
$$
dilakukan, elang laut yang menjadi mangsa tidak pernah melakukan aktivitas makan karena selalu diganggu oleh elang lainnya. Elang laut yang menjadi mangsa sudah menjadi sangat lemah, karena semakin hari elang laut tersebut berdiam di lokasi yang lebih rendah sampai akhirnya hanya berdiam di tanah sebelum ditemukan telah di mangsa oleh elang yang lain.

Elang laut lebih banyak melakukan tingkah laku makan sesama jenis dibanding makan ikan yang disediakan dikolam. Rata-rata elang laut akan memakan bangkai dari mangsanya 3 kali sehari atau meningkat 50\%. Selain lebih sering melakukan tingkah laku makan, elang laut juga sering melakukan perkelahian atau agonistik. Aktivitas makan elang laut sebanyak 33\% di ikuti dengan perkelahian selama memakan bangkai. Hal tersebut menunjukan bahwa tingkat kesukaan elang laut dalam memakan sesama jenisnya lebih tinggi dibandingkan dengan memakan ikan yang berada dikolam. Akibat sering terjadi perkelahian selama kanibalisme terjadi, variasi penggunaan waktu untuk aktivitas makan menjadi sangat tinggi. 
Elang laut akan mengeluarkan suara-suara yang cukup keras saat mengamati mangsa sebelum akhirnya turun dan memakan bangkai dari elang laut lainnya. Tingkat penggunaan waktu pada tahap makan dari elang laut meningkat menjadi $97 \%$ dan mengamati tetap 3\% yang mana rata-rata elang laut menggunakan 25 detik untuk mengamati dan 764 detik untuk tahap makan. Selain peningkatan intensitas makan elang laut yang mencapai $50 \%$ saat memakan bangkai elang laut lainnya, penggunaan waktu aktivitas makan elang laut meningkat hampir hampir tiga kali lipat.

Selain peningkatan intensitas makan yang dilakukan oleh elang laut, penggunaan waktu makan yang dilakukan elang laut juga meningkat. Beberapa faktor yang mempengaruhi peningkatan penggunaan waktu makan adalah gangguan dari elang lainnya, perubahan lokasi makan dan kondisi bangkai yang akan dimakan. Namun aktivitas-aktivitas yang terjadi di luar kandang sudah tidak terlalu mempengaruhi elang laut saat makan.

Lokasi makan elang laut yang dianggap tidak sesuai akan membuat elang laut memindahkan makanannya dengan cara menarik makanan menggunakan paruh. Berat dan ukuran dari bangkai elang laut yang akan dimakan akan cukup menyulitkan untuk dipindahkan dan membuat waktu yang sedikit lebih lama dibandingkan dengan memindahkan ikan air tawar dari dalam kolam. Ketika telah berpindah tempat elang laut tidak akan berpindah tempat lagi kecuali terdapat gangguan dari elang lainnya.

Perbedaan tingkah laku makan elang laut yang sangat tinggi diakibatkan karena elang laut jarang memakan bangkai elang lainya selama dipelihara di Pusat Penyelamatan Satwa Tasikoki. Perubahan makanan tersebut juga semakin memperjelas dominasi antar elang laut yang ada di dalam kandang karena meningkatnya tingkah laku agonistik yang terjadi.

\section{KESIMPULAN}

Elang laut perut putih yang dipelihara di Pusat Penyelamatan Satwa Tasikoki melakukan aktivitas makan $8 \%$ dalam aktivitas hariannya dan makanan yang dikonsumsi elang laut adalah ikan yang disediakan dalam kolam serta memakan sesama jenisnya sendiri. Elang laut menggunakan 3\% waktunya untuk mengamati, $1 \%$ untuk menangkap mangsa dan waktu paling banyak adalah untuk memakan mangsa 96\% saat memangsa ikan . Intensitas makan elang laut meningkat $50 \%$ saat melakukan kanibalisme dibanding memakan ikan. 


\section{DAFTAR PUSTAKA}

Alikodra, 2002. Teknik Pengelolaan Satwa Liar. Fakultas Kehutanan IPB. Bogor

International Union Conservation Nature. (2012). Haliaeetus leucogaster. Di unduh tahun 2014 terdapat pada :http://www.iucnredlist.org/ details /22695097/0.: Iucnredlist.org.

Lee. (2010). Breeding Ecology of Whitebellied Sea Eagle (Haliaeetus leucogaster) In Hongkong. Agriculture, Fiesher And Biodiversity Hongkong Department Newsletter. Hongkong.

PPS Tasikoki. 2014. Pusat Penyelamatan Satwa Tasikoki. tasikoki.org. Minahasa Utara.

Sawitri, R dan M. Takandjandji. 2010. Pengelolaan Dan Perilaku Burung Elang Di Pusat Penyelamatan Satwa Cikananga Sukabumi. Pusat Penelitian dan Pengembangan
Hutan dan Konservasi Alam. Bogor.

Tan, 2001. White-Bellied Fish Eagle. Sungei Buloh Nature Park. Malaysia. di unduh tahun 2014 terdapat pada http://www.naturia.per.sg /buloh/birds/Haliaeetus leucogaster.htm 2014.

Wihoho. 2007. Program Pelepasliaran Elang Brontok (Spizaetus cirrhatus) Di Kawasan Pura Batukaru, Tabanan. Balai Konservasi Sumber Daya Alam Bali. Bali. 